\title{
The Protective Effect of Melatonin on Plasma Lipid Profile in Rats with Cerulein-induced Acute Pancreatitis
}

\author{
Ercan KESKINN ${ }^{1}$ Deniz ULUIŞIK ${ }^{1}$
}

${ }^{1}$ Department of Physiology, Faculty of Veterinary Medicine, University of Selcuk, Konya, Turkey
Address Correspondence to Department of Physiology, Faculty of Veterinary Medicine,University of Selcuk, Konya, Turkey denizfedai@selcuk.edu.tr

\begin{abstract}
The objective of this study was to assessment the effect of melatonin on lipid profile in rats with experimentally induced acute pancreatitis. In this study, 32 adult, male, healthy Wistar Abino rats were used. Group I animals was no applied. Group II animals was intraperitoneally administered $50 \mathrm{mg} / \mathrm{kg}$ melatonin per rat twice for two hours intervals. Animals of group III received two intraperitoneal injections of cerulein $(50 \mu \mathrm{g} / \mathrm{kg}$ and $25 \mu \mathrm{g} / \mathrm{kg}$ bw, respectively) at two hours intervals. Animals of group IV received two intraperitoneal injections of cerulein $(50 \mu \mathrm{g} / \mathrm{kg}$ and $25 \mu \mathrm{g} / \mathrm{kg}$ bw, respectively) at two hours intervals and the rats received an intraperitoneal injection of $50 \mathrm{mg} / \mathrm{kg}$ melatonin $30 \mathrm{~min}$ before each cerulein injection.After 12 hours from the last cerulein injection, total cholesterol, triglyceride, LDL, HDL levels was determined.In this study, experimentally induced acute pancreatitis resulted in significantly increase in levels of total cholesterol, triglyceride and LDL ( $<<0.05)$, while HDL level significantly decreased compared with control group level $(\mathrm{p}<0.05)$. Pretreatment of melatonin to the rats with acute pancreatitis importantly reduced triglyceride and LDL levels compared to pancreatitis group ( $\mathrm{p}<0.05$ ).In conclusion, melatonin pretreatment may alleviate the abnormalities in plasma lipid profilecaused by acute pancreatitis.
\end{abstract}

Key words: Cerulein, melatonin, acute pancreatitis, lipid profile, rats

\section{INTRODUCTION}

Acute pancreatitis (AP) is noninfectious inflammatory disorder of pancreas representing variable severity ranging from mild to severe inflammatory cascade associated with multipleorgan failure. $(38,45)$. The incidence of this disease is increasing in the worldwide(11). Acute pancreatitis is characterized with parenchymal edema, tissue necrosis, hemorrhage and inflammatory cell infiltration $(2,11,24,29,35,43,59$, 60). A number of pathophysiological processes of acute pancreatitis include inflammation, apoptosis, necrosis and oxidative stress (28). Researches have been focused on dyslipidemia during the course of acute pancreatitis and about relationship between hypertriglyceridemia and acute pancreatitis $(13,18$, 26). Despite developments in treatment of the disease, acute pancreatitis has still high morbidity and mortality rates reaching up to $30 \%$ in severe cases $(7,49)$. In treatment of the disease, new approaches and use of alternative medicinal agents are continued to investigate due to its complex etiology and clinical course.

Melatonin (N-acetyl-5-methoxytrptamine) known as major pineal secretory product is also synthesized in other organs and tissues such as retina, lens, bone marrow cells, gastrointestinal tract and skin. (48). Melatonin has several physiological functions including control of reproductive activity in seasonally reproductive animals, sleep promotion, circadian regulation and modulation of immune responsiveness. (44).In addition, melatonin effectively reduces oxidative stress viamany mechanisms $(44,48,53)$. Melatonin detoxifies highly toxic hydroxyl and peroxyl radicals. It has been reported that melatonin increased the synthesis of glutathione and several antioxidant enzymes. (47, 52).Numerous experimental studies have shown that melatonin is not only an important antioxidant but also an important anti-inflammatory molecule $(1,5,9,19,21,23,37)$. Thus, melatonin has been clinically interest regarding these properties (21). 
Also, earlier studies reported that melatonin has effects on lipid metabolism (16). It has been noted that melatonin lowered serum, hepatic, adrenal and testicular cholesterol levels. In consistent with above results, pinealectomy caused the opposite effects on lipid parameters. There are also other studies about this lowering effect of melatonin on serum cholesterol and triglyceride.(20, 30, 39,52, 56). The objective of this study was to assessment the effect of melatonin on lipid profile in rats with experimentally induced acute pancreatitis.

degrees, it is considered that the knee joint causes deterioration of the extension mechanism and patella causes femoral pain with increasing tendency to slide laterally (3). It has been emphasized that it causes various pain and disability in abnormally low values (19).

\section{MATERIAL AND METHOD}

In the study, 32 adult (6 weeks), male, healthy Wistar Abino rats were used. The animals were divided into four groups. All animals were fasted before at the beginning of study, while it allowed to drink water. The study protocol was approved by The Ethical Committee of Selçuk University Experimental Medicine Research and Application Center(Report no. 2017-16).

Group Ianimals(n=6) was no applied. Group II animals(n=6) was intraperitoneally administered $50 \mathrm{mg} / \mathrm{kg}$ melatonin (Sigma-Aldrich, St. Louis, MO, USA) per rat twice for two hours intervals. Animals of group III $(n=10)$ received two intraperitoneal injections of cerulein (Sigma-Aldrich, St. Louis, MO, USA) (50 $\mu \mathrm{g} / \mathrm{kg}$ and $25 \mu \mathrm{g} / \mathrm{kg}$ bw, respectively) at two hours intervals. Animals of group IV $(n=10)$ received two intraperitoneal injections of cerulein (50 $\mu \mathrm{g} / \mathrm{kg}$ and $25 \mu \mathrm{g} / \mathrm{kg} \mathrm{bw}$, respectively) at two hours intervals and the rats received an intraperitoneal injection of $50 \mathrm{mg} / \mathrm{kg}$ melatonin 30 min before each cerulein injection.After 12 hours from the last cerulein injection, blood samples were taken from all animals. It was determined total cholesterol, triglyceride, LDL, HDL levels in the Abbott C8200autoanalyzer using Abbott kits in these blood samples.
The data obtained from the study were analyzed by one-way ANOVA (SPSS 19).Differences among the groups were determined by Duncan's multiple range test. Differences were considered significant at $\mathrm{p}<0.05$.

\section{RESULTS}

The effect of melatonin on lipid profile in experimentally induced acute pancreatitis was summarized in Table 1. In this study, experimentally induced acute pancreatitis resulted in significantly increase in levels of total cholesterol, triglyceride and LDL $(p<0.05$, Table 1$)$, while HDL level significantly decreased compared with control group level $(p<0.05$, Table 1). Melatonin administration to intact animals caused some fluctuations in all parameters but these changes were not important. Pretreatment of melatonin to the rats with acute pancreatitis importantly reduced triglyceride and LDL levels compared to pancreatitis group ( $\mathrm{p}<0.05$, Table 1$)$. Occurred changes in total cholesterol and HDL levels with melatonin treatment to the rats with acute pancreatitis were not important.

\section{DISCUSSION}

In this study, the changes in lipid parameters in acute pancreatitis are consistent with some studies which reported severe acute pancreatitis can alter lipid profile $(6,32)$. In acute pancreatitis cases, high triglyceride level is most common data. In generally, low HDL level, high LDL and cholesterol levels accompanied to hypertriglyceridemia in acute pancreatitis $(6,57)$. It has been reported that high concentration of triglycerides and low HDL level are associated with severity of acute pancreatitis (14, 54). It was suggested that HDL has antiinflammatory and antioxidant properties (6, 12, 34, $46,55)$ and low HDL level may be associated with an increase in severity of the disease due to decrease in anti-inflammatory and antioxidant activity of HDL (57). Carpentier and Scruel (8)reported that production of triglycerides increased in the liver and lipoprotein lipase activity decreased during acute pancreatitis. It was noted that these events might lead to higher serum triglycerides concentration (8, 32).

Bonjoch et al. (4) have previously reported that inflammatory mediators promoted the progression of inflammation in acute pancreatitis. It was stated that the activation of macrophages by inflammatory cytokines from adipose tissue 
increased the inflammatory response during pancreatitis $(4,25,36,51)$. In parallel to above knowledge, it was notedthat free fatty acids, oxidized lipids, halogenated lipids and bioactive lipid mediator's production increased during acute pancreatitis $(4,15,22,27,41)$. There are notifications that inflammatory cytokines induced hepatic synthesis of acute phase proteins and low level of HDL is associated with high levels of inflammatory cytokines. It has been suggested that high levels of inflammatory cytokines impaired biosynthesis of HDL and also facilitated degradation of lipoprotein (45).

Based on antioxidant and anti-inflammatory properties of melatonin, pretreatment of melatonin to the rats with acute pancreatitis importantly reduced triglyceride and LDL levels compared to pancreatitis group $(\mathrm{p}<0.05$, Table 1$)$.Túnez et al. (56) reported that cholesterol, phospholipids, triglycerides and free fatty acids levels decreased in the brain and liver of melatonin-treated rats. Hoyos et al. (30) suggested that melatonin could promote augmenting the clearance of endogenous cholesterol. Melatonin administration to rats fed with high-cholesterol diet reduced total cholesterol and LDL and prevented a decrease in HDL (30). It also improved fatty liver induced by high-fat diets that affect serum lipids (42).

In ovariectomized rats, it has been noted that melatonin administration prevented increase in body mass and cholesterol concentration (50).A lowering effect of long term melatonin treatment on serum cholesterol has been reported in adult rats (3, 39) and hamsters (58). In another study, it was suggested that short term melatonin treatment decreased free cholesterol level in rats, presumably by augmenting lecithin-cholesterol acyltransferasemediated cholesterol esterification (20).

Our results are consistent with above studies which have been shown improvement in lipid profile after melatonin treatment. Lipid lowering effect of melatonin were attributed to several mechanism such as decrease in intestinal cholesterol absorption (31), inhibition of cholesterol biosynthesis and LDL accumulation (10), interactions with LDL receptors (40) or inhibition of fatty acid transport via metabotropic receptors (17, 33).

\begin{tabular}{|c|c|c|c|c|}
\hline & $\begin{array}{l}\text { Total Cholesterol } \\
(\mathrm{mg} / \mathrm{dl})\end{array}$ & $\begin{array}{c}\text { Triglyceride } \\
(\mathrm{mg} / \mathrm{dl})\end{array}$ & $\begin{array}{c}\text { LDL } \\
(\mathrm{mg} / \mathrm{dl})\end{array}$ & $\begin{array}{c}\text { HDL } \\
(\mathrm{mg} / \mathrm{dl})\end{array}$ \\
\hline Group I & $95,83 \pm 4,01^{\text {bc }}$ & $67,17 \pm 4,69^{\mathrm{b}}$ & $51,67 \pm 1,28^{b}$ & $42,50 \pm 2,86^{\mathrm{a}}$ \\
\hline Group II & $89,33 \pm 5,35^{c}$ & $61,50 \pm 3,33^{b}$ & $45,17 \pm 3,50^{\mathrm{b}}$ & $43,83 \pm 3,27^{a}$ \\
\hline Group III & $118,20 \pm 3,17^{a}$ & $86,70 \pm 3,58^{a}$ & $64,90 \pm 3,35^{a}$ & $31,40 \pm 3,57 \mathrm{~b}$ \\
\hline Group IV & $107,50 \pm 3,66^{\mathrm{ab}}$ & $72,60 \pm 4,00^{b}$ & $53,30 \pm 3,61^{b}$ & $36,10 \pm 2,59^{a b}$ \\
\hline
\end{tabular}

a-c The difference between mean values with different superscripts in the same column is significant at the $p<0.05$ level.

\section{Conclusions}

Moved on our results, it was considered that melatonin pretreatment in rats with acute pancreatitis may be useful to alleviate the abnormalities of lipid profile caused by acute pancreatitis. 


\section{REFERENCES}

1. Agil A, Reiter RJ, Jiménez-Aranda A, Ibán-Arias R, NavarroAlarcón M, Marchal JA, Adem A, Fernández-Vázquez G.Melatonin ameliorates low-grade inflammation and oxidative stress in young Zucker diabetic fatty rats. J Pineal Res, 2013; 54(4): 381-388.

2. Akay C, Yaman H, Oztosun M, Cakir E, Yildirim AO, Eyi YE, Agilli M, Akgul EO, Aydin I, Kaldirim U, Tuncer SK, Eken A, Oztas E,Poyrazoglu Y, Yasar M, Ozkan Y.The protective effects of taurine on experimental acute pancreatitis in a rat model. Hum ExpToxicol,2013; 32(5): 522-529.

3. Aoyama H, Mori N, Mori W. Effects of melatonin on genetic hypercholesterolemia in rats. Atherosclerosis, 1988; 69(2-3): 269-272.

4. Bonjoch L, Gea-Sorlí S, Closa D. Lipids generated during acute pancreatitis increase inflammatory status of macrophages by interfering with their M2 polarization. Pancreatology, 2015; 15(4): 352-359.

5. Bonnefont-Rousselot D, Collin F, Jore D, Gardès-Albert M.Reaction mechanism of melatonin oxidation by reactive oxygen species in vitro. J Pineal Res, 2011; 50(3): 328-335.

6. Bugdaci MS, Sokmen M, Zuhur SS, Altuntas Y.Lipid profile changes and importance of low serum- $\alpha$-lipoprotein fraction (high-density lipoprotein) in cases with acute pancreatitis. Pancreas,2011; 40(8): 1241-1244.

7. Bukowczan J, Warzecha Z, Ceranowicz P, Kuśnierz-Cabala B, Tomaszewska R.Obestatin accelerates the recovery in the course of ischemia/reperfusion-induced acute pancreatitis in rats. PLoS One, 2015; 10(7): e0134380.

8. Carpentier YA, Scruel O. Changes in the concentration and composition of plasma lipoproteins during the acute phase response. CurrOpinClinNutrMetab Care, 2002; 5(2): 153-158.

9. Carrillo-Vico A, Lardone PJ, Alvarez-Sánchez N, RodríguezRodríguez A, Guerrero JM. Melatonin: buffering the immune system. Int J MolSci, 2013; 14(4): 8638-8683.

10. Chan TY, Tang PL.Effect of melatonin on the maintenance of cholesterol homeostasis in the rat. Endocr Res, 1995; 21(3): 681-696.

11. Chan YC, Leung PS.The Renin-angiotensin system and reactive oxygen species: implications in pancreatitis. Antioxid Redox Signal,2011; 15(10): 2743-2755.

12. Chen $X$, Wu Y, Liu L, Su Y, Peng Y, Jiang L, Liu X, Huang D.Relationship between high density lipoprotein antioxidant activity and carotid arterial intima-media thickness in patients with essential hypertension. ClinExpHypertens, 2010; 32(1): 13-20.

13. Cheng L, Luo Z, Xiang K, Ren J, Huang Z, Tang L, Tian F.Clinical significance of serum triglyceride elevation at early stage of acute biliary pancreatitis. BMC Gastroenterol, 2015; 15(1): 19.

14. Chikamune T,Katamoto H, Nomura K, Ohashi F.Lipoprotein profile in canine pancreatitis induced with oleic acid. J Vet Med Sci, 1998; 60(4): 413-421.

15. Closa D, Bulbena O, Rosello-Catafau J, Fernandez-Cruz L, Gelpi E.Effect of prostaglandins and superoxide dismutase administration on oxygen free radical production in experimental acute pancreatitis. Inflammation,1993; 17(5): 563571.

16. Damian E. The role of the pineal gland in the lipid metabolism. Endocrinologie, 1978; 16(3): 179-189.

17. Dauchy RT, Blask DE, Sauer LA, Davidson LK, Krause JA, Smith LC, Dauchy EM. Physiologic melatonin concentration, omega-3 fatty acids, and conjugated linoleic acid inhibit fatty acid transport in rodent hind limb skeletal muscle in vivo. Comp Med, 2003; 53(2): 186-190.
18. Domínguez-Muñoz JE, Jünemann $\mathrm{F}$, Malfertheiner $\mathrm{P}$. Hyperlipidemia in acute pancreatitis. Cause or epiphenomenon?.Int J Pancreatol, 1995; 18(2): 101-106.

19. Dong $Y$, Fan $C, H u$ W, Jiang S, Ma Z, Yan X, Deng C, Di S, Xin $\mathrm{Z}, \mathrm{Wu}$ G, Yang Y, Reiter RJ, Liang G.Melatonin attenuated early brain injury induced by subarachnoid hemorrhage via regulating NLRP3 inflammasome and apoptosis signaling. J Pineal Res, 2016; 60(3): 253-262.

20. Esquifino A, Agrasal C, Velazquez E, Villanua MA,Cardinali DP. Effect of melatonin on serum cholesterol and phospholipid levels, and on prolactin, thyroid-stimulating hormone and thyroid hormone levels, in hyperprolactinemic rats. Life Sci, 1997; 61(11): 1051-1058

21. Favero G, Franceschetti L, Bonomini F, Rodella LF, Rezzani R.Melatonin as an anti-inflammatory agent modulating inflammasome activation. Int J Endocrinol, 2017; 2017: Article ID 1835195, 1-13.

22. Franco-Pons N, Casas J, Fabriàs G, Gea-Sorlí S, de-Madaria E, Gelpí E, Closa D.Fat necrosis generates proinflammatory halogenated lipids during acute pancreatitis. Ann Surg,2013; 257(5): 943-951.

23. Galano A, Tan DX, Reiter RJ.Melatonin as a natural ally against oxidative stress: a physicochemical examination. J Pineal Res, 2011; 51(1): 1-16.

24. Galuppo M, Nocentini G, Mazzon E, Ronchetti S, Esposito E, Riccardi L, Sportoletti P, Di Paola R, Bruscoli S, Riccardi C, Cuzzocrea $S$.The glucocorticoid-induced TNF receptor familyrelated protein (GITR) is critical to the development of acute pancreatitis in mice. Br J Pharmacol,2011; 162(5): 1186-1201.

25. Gea-Sorlí S, Bonjoch L, Closa D.Differences in the inflammatory response induced by acute pancreatitis in different white adipose tissue sites in the rat. PLoS One, 2012; 7(8): e41933.

26. Gillies NA, Pendharkar SA, Singh RG, Asrani VM, Petrov MS.Lipid metabolism in patients with chronic hyperglycemia after an episode of acute pancreatitis. Diabetes MetabSyndr, 2017; 11S: S233-S241.

27. Gutierrez PT, Folch-Puy E, Bulbena O, Closa D.Oxidised lipids present in ascitic fluid interfere with the regulation of the macrophages during acute pancreatitis, promoting an exacerbation of the inflammatory response. Gut,2008; 57(5): 642-648.

28. Hammer HF. An update on pancreatic pathophysiology (do we have to rewrite pancreatic pathophysiology?). Wien Med Wochenschr, 2014; 164(3-4): 57-62.

29. Hartman H, Abdulla A, Awla D, Lindkvist B, Jeppsson B, Thorlacius H, Regnér S.P-selectin mediates neutrophil rolling and recruitment in acute pancreatitis. Br J Surg, 2012; 99(2): 246-255.

30. Hoyos M, Guerrero JM, Perez-Cano R, Olivan J, Fabiani F, Garcia-Perganeda A, Osuna C. Serum cholesterol and lipid peroxidation are decreased by melatonin in diet-induced hypercholesterolemic rats. J Pineal Res, 2000; 28(3): 150-155.

31. Hussain SA. Effect of melatonin on cholesterol absorption in rats. J Pineal Res, 2007; 42(3): 267-271.

32. Khan J, Nordback I, Sand J.Serum lipid levels are associated with the severity of acute pancreatitis.Digestion,2013; 87(4): 223-228.

33. Koziróg M, Poliwczak AR, Duchnowicz P, Koter-Michalak M, Sikora J, Broncel M. Melatonin treatmentimprovesbloodpressure, lipidprofile, andparameters of oxidativestress in patientswithmetabolicsyndrome.J PinealRes, 2011; 50(3): 261-266.

34. Lee JH, Park JH, Lee SH, Kim JR, Cho KH.Elevated HDL2paraoxonase and reduced CETP activity are associated with dramatically lower ratio of LDL-cholesterol/total cholesterol in 
a hypercholesterolemic and hypertriglyceridemic patient. Int J Mol Med, 2010; 25(6): 945-951.

35. Liu M, Shi L, Chen M, Chen S, Zou X.Effects of c-Jun Nterminal kinase signaling pathway on severe acute pancreatitis-associated lung injury. Pancreas,2012; 41(3): 358366.

36. Mårin $\mathrm{P}$, Andersson B, Ottosson $\mathrm{M}$, Olbe L, Chowdhury B, Kvist H, Holm G, Sjöström L, Björntorp P.The morphology and metabolism of intraabdominal adipose tissue in men. Metabolism,1992; 41(11): 1242-1248.

37. Mauriz JL, Collado PS, Veneroso C, Reiter RJ, GonzálezGallego J.A review of the molecular aspects of melatonin's anti-inflammatory actions: recent insights and new perspectives. J Pineal Res, 2013; 54(1): 1-14.

38. Mirmalek SA, Boushehrinejad AG, Yavari H, Kardeh B, Parsa Y, Salimi-Tabatabaee SA, Yadollah-Damavandi S, Parsa T, Shahverdi E, Jangholi E. Antioxidant and anti-inflammatory effects of coenzyme Q10 on L-Arginine-induced acute pancreatitis in rat. Oxid Med Cell Longev, Article ID 5818479, 2016; 2016: 1-8.

39. Mori N, Aoyama H, Murase T, Mori W. Antihypercholesterolemic effect of melatonin in rats. ActaPatholJpn, 1989; 39(10): 613-618.

40. Müller-Wieland D, Behnke B, Koopmann K, Krone W.Melatonin inhibits LDL receptor activity and cholesterol synthesis in freshly isolated human mononuclear leukocytes. BiochemBiophys Res Commun, 1994; 203(1): 416-421.

41. Navina S, Acharya C, DeLany JP, Orlichenko LS, Baty CJ, Shiva SS, Durgampudi C, Karlsson JM, Lee K, Bae KT, Furlan A, Behari J, Liu S, McHale T, Nichols L, Papachristou GI, Yadav D, Singh VP.Lipotoxicity causes multisystem organ failure and exacerbates acute pancreatitis in obesity. SciTransl Med,2011; 3(107): 107-110.

42. Pan $\mathrm{M}$, Song $\mathrm{YL}, \mathrm{Xu}$ JM, Gan HZ.Melatonin ameliorates nonalcoholic fatty liver induced by high-fat diet in rats. J Pineal Res, 2006; 41(1): 79-84.

43. Pan Z, Feng L, Long H, Wang H, Feng J, Chen F. Effects of local pancreatic renin-angiotensin system on the microcirculation of rat with severe acute pancreatitis. Korean J PhysiolPharmacol, 2015; 19(4): 299-307.

44. Pandi-Perumal SR, Srinivasan V, Maestroni GJ, Cardinali DP, Poeggeler B, Hardeland R.Melatonin: nature's most versatile biological signal?. FEBS J, 2006; 273(13): 2813-2838.

45. Peng YS, Chen YC, Tian YC, Yang CW, Lien JM, Fang JT, Wu CS, Hung CF, Hwang TL, Tsai YH, Lee MS, Tsai MH.Serum levels of apolipoprotein A-I and high-density lipoprotein can predict organ failure in acute pancreatitis. Crit Care, 2015; 19, 88: 1-9.

46. Podrez EA. Antioxidant properties of high density lipoprotein and atherosclerosis. ClinExpPharmacolPhysiol, 2010; 37(7): 719-725.

47. Reiter RJ, Carneiro RC, Oh CS.Melatonin in relation to cellular antioxidative defense mechanisms. HormMetab Res, 1997; 29(8): 363-372.

48. Reiter RJ, Tan DX, Terron MP, Flores LJ, Czarnocki Z. Melatonin and its metabolites: new findings regarding their production and their radical scavenging actions. ActaBiochim Pol, 2007; 54(1): 1-9.

49. Rohan Jeyarajah D, Osman HG, Patel S. Severe acute pancreatitis attacks are associated with significant morbidity and mortality. CurrProblSurg, 2014; 51(9): 370-372.

50. Sanchez-Mateos S, Alonso-Gonzalez C, Gonzalez A, MartinezCampa CM, Mediavilla MD, Cos S, Sanchez-Barcelo EJ.Melatonin and estradiol effects on food intake, body weight, and leptin in ovariectomized rats. Maturitas, 2007; 58(1): 91101.

51. Sempere L, Martinez J, de Madaria E, Lozano B, Sanchez-Paya J, Jover R, Perez-Mateo M. Obesity and fat distribution imply a greater systemic inflammatory response and a worse prognosis in acute pancreatitis. Pancreatology,2008; 8(3): 257264.

52. Subramanian P, Mirunalini S, Pandi-Perumal SR, Trakht I, Cardinali DP.Melatonin treatment improves the antioxidant status and decreases lipid content in brain and liver of rats. Eur J Pharmacol, 2007; 571(2-3): 116-119.

53. Tan DX, Manchester LC, Terron MP, Flores LJ, Reiter RJ. One molecule, many derivatives: a never-ending interaction of melatonin with reactive oxygen and nitrogen species? J Pineal Res, 2007; 42(1): 28-42.

54. Toskes PP.Hyperlipidemic pancreatitis. GastroenterolClin North Am, 1990; 19(4): 783-791.

55. Tribble DL, Chu BM, Gong EL, van Venrooij F, Nichols AV.HDL antioxidant effects as assessed using a nonexchangeable probe to monitor particle-specific peroxidative stress in LDL-HDL mixtures. J Lipid Res,1995; 36(12): 2580-2589.

56. Túnez L, Muñoz MC, Feijoo-López AL, Valdvira E, BujalanceArenas L, Montilla P.Effect of melatonin on hyperlipidemic nephropathy under constant light exposure. J PhysiolBiochem, 2002; 58(2): 109-114.

57. Unal E, Uzun H, Kusaslan R, Dogan M, Genc H, Gunes P, Titiz I.Serum paraoxonase (a high-density lipoprotein-associated lipophilic antioxidant) activity and lipid profile in experimental acute pancreatitis. Pancreas,2005; 31(1): 84-87.

58. Vaughan MK, Powanda MC, Brainard GC, Johnson LY, Reiter RJ. Effects of blinding or afternoon melatonin injections on plasma cholesterol, triglycerides, glucose, TSH and thyroid hormone levels in male and female Syrian hamsters. ProgClinBiol Res, 1982; 92: 177-186.

59. Yang B, Bai B, Liu CX, Wang SQ, Jiang $X$, Zhu CL, Zhao QC.Effect of umbilical cord mesenchymal stem cells on treatment of severe acute pancreatitis in rats. Cytotherapy,2013; 15(2): 154-162.

60. Yubero S, Manso MA, Ramudo L, Vicente S, De Dios I.Dexamethasone down-regulates the inflammatory mediators but fails to reduce the tissue injury in the lung of acute pancreatitis rat models. PulmPharmacolTher,2012; 25(4): 319324. 